TECHNICAL TRANSACTIONS 9/2018

CIVIL ENGINEERING

DOI: $10.4467 / 2353737$ XCT.18.137.8976 SUBMISSION OF THE FINAL VERSION: 17/8/2018

\author{
Bartłomiej Ziarko (D) orcid.org/0000-0002-8836-5586 \\ bziarko@pk.edu.pl \\ Division of Building and Building Physics, Institute of Building Materials and Structures, \\ Cracow University of Technology
}

\title{
ADAPTATION OF COUTYARDS INTO COVERED AND GLAZED ATRIUMS \\ AND ITS IMPACT ON THE LEVEL OF ACOUSTIC COMFORT INSIDE
}

- CASE STUDY

\author{
ADAPTACJA ZAMKNIĘTYCH DZIEDZIŃCÓW NA ZADASZONE \\ I PRZESZKLONE ATRIA ORAZ JEJ WPŁYW NA POZIOM KOMFORTU \\ AKUSTYCZNEGO WNĘTRZA -STUDIUM PRZYPADKU
}

\begin{abstract}
Increasingly popular, in the area of modernization or revitalization of historic buildings, is the creation of a roof that is often fully glazed over the inner courtyard, thus creating a new spacious interior capable of performing many functions. The acoustics evaluation undertaken in this article was carried out on the basis of measurements and simulation of reverberation time in The Home Army Museum building in Cracow.
\end{abstract}

Keywords: architecture, atrium, acoustics; architectural acoustics; room acoustics

\section{Streszczenie}

Coraz popularniejsze staje się w ramach rewitalizacji zabytkowych obiektów wykonanie zadaszenia nad dziedzińcem wewnętrznym i stworzenia tym samym nowego przestronnego wnętrza mogącego pełnić bogate funkcje. Podjęta w artykule ocena akustyki wnętrza została wykonana na podstawie pomiarów i symulacji czasu pogłosu w budynku Muzeum Armii Krajowej w Krakowie

Słowa kluczowe: architektura, atrium, akustyka, akustyka wnętrz 


\section{Symbols}

$T_{20,} T_{60}, R T$ - reverberation time [s],

$T_{\text {pref }} \quad-$ preferred reverberation time $[\mathrm{s}]$,

$V \quad-$ room interior volume $\left[\mathrm{m}^{3}\right]$,

A - total acoustic absorption of the room,

S $\quad-$ overall interior surface area $\left[\mathrm{m}^{2}\right]$,

$\alpha_{s r} \quad-$ average sound absorption coefficient.

\section{Introduction}

Courtyards in historical buildings usually have a significant utilitarian and representative role; its form and dimensions often represent the social and material status of the owner. It could be a place for meetings, celebrations, or a space used for rest. Nowadays, the role of the courtyard has not changed significantly, but the current user expectations and requirements have indicated the need to revise the arrangement of these spaces. Increasingly popular, in the area of modernization or revitalization of historic buildings, is the creation of a roof that is often fully glazed over the inner courtyard, thus creating a new spacious interior capable of performing many functions. Primary contact with nature and the outside environment is preserved, as is the plasticity of the resulting structure. It also enhances visual experiences, which are not limited by the layers of the roof [1].

A new design allows one to use such a room in many new ways. It creates space for exhibitions, chamber concerts, lectures, film screenings, art exhibitions, installations and sculptures whose form and scale would not allow exposure in traditional spaces. These solutions bring many benefits, extend the functionality of the building, and increase both the usable area and the value of the object itself [2], but present the designer with a number of challenges that must be overcome at the concept stage. During the design phase of such an adaptation, the architect most often focuses on creating the best form, function, and construction of the whole object without delving into time-consuming analyses of how their decision will affect the acoustic comfort of the interior. This is not due to a lack of willingness but to a shortage of suitable design tools that could improve the design process in the context of acoustics.

Finishing the interior exclusively with hard and smooth materials, without the use of sound absorbing materials, increases the noise level and prolongs the reverberation time. People in such interiors will have difficulties communicating with each other which can lead to the Lombard's effect: the tendency of the interlocutors to gradually increase the intensity of their voices when the conversation takes place in loud environments. Reverberation time is the basic parameter for acoustic evaluation of interiors and, in order to reduce it, the best solution is to use tested interior sound absorbing materials. Acoustical performance of atriums cannot be expected to be on par with lecture rooms or concert halls, but attention should be paid to the application and even distribution of sound absorption in the existing interior [3]. Assessment of interior acoustics in this article was made on the basis of measurements and simulations of reverberation time $\left(T_{20}\right)$. 


\section{Description of the case study}

The courtyard selected for the assessment of the interior acoustic comfort is located in The Home Army Museum in Cracow. (Fig. 1). The building was formerly a military facility and was part of a unique architectural complex of the former Cracow fortress. In 2011, the revitalization of the facility was completed. The exterior of the building did not change, as the renovation work was focused on preserving the original character of the building [4].

a)

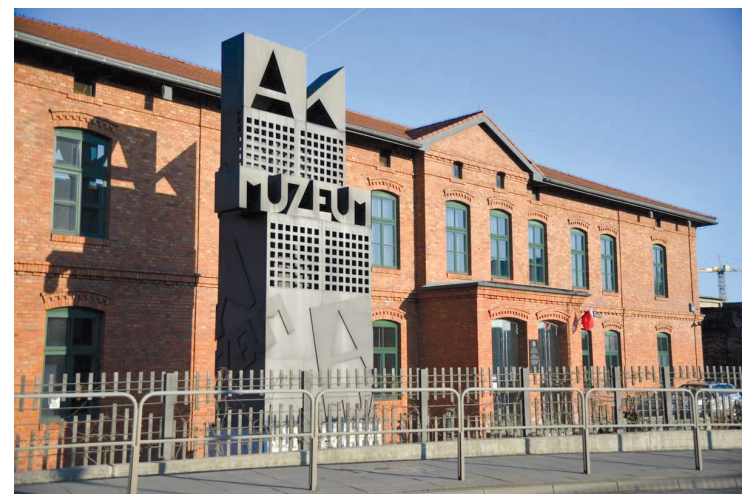

b)

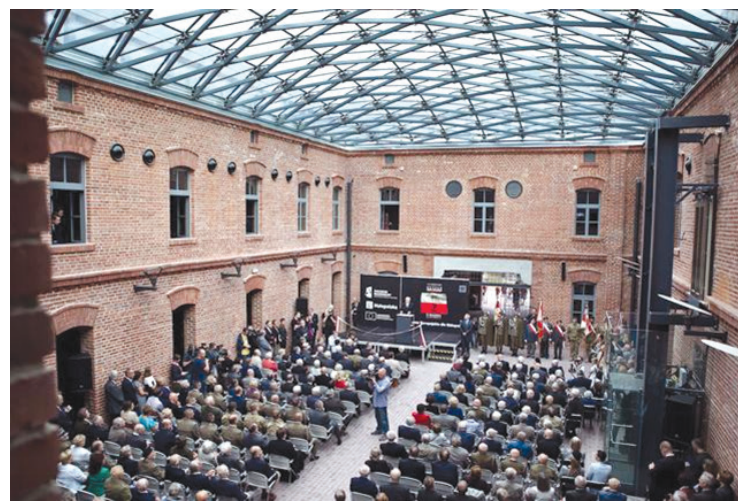

Fig. 1. a) The Home Army Museum front elevation (source: [11]); b) Interior of the atrium (source: [12])

External facades have been cleaned, windows have been replaced and the roof sheathing has been covered with ceramic tiles. The biggest changes took place in the interior. The facades of the courtyard were rebuilt with a glass roof made over them. The newly built room not only became an impressive exhibition area, but also "the heart" of the whole building. The atrium, apart from the communication and exhibition function, is also a place where various types of productions, lectures, and even concerts are organized. (Fig. 2).

The dimensions of the hall are approximately $15 \times 27 \mathrm{~m}$, and the height of the roof varies between 9-12 m. The atrium's volume is approximately $V=4455 \mathrm{~m}^{3}$ with a total area of interior surfaces at around $S=1735 \mathrm{~m}^{2}$. The main materials used for interior finishes are ceramic bricks, plaster, steel, wood and glass (Fig. 2). 


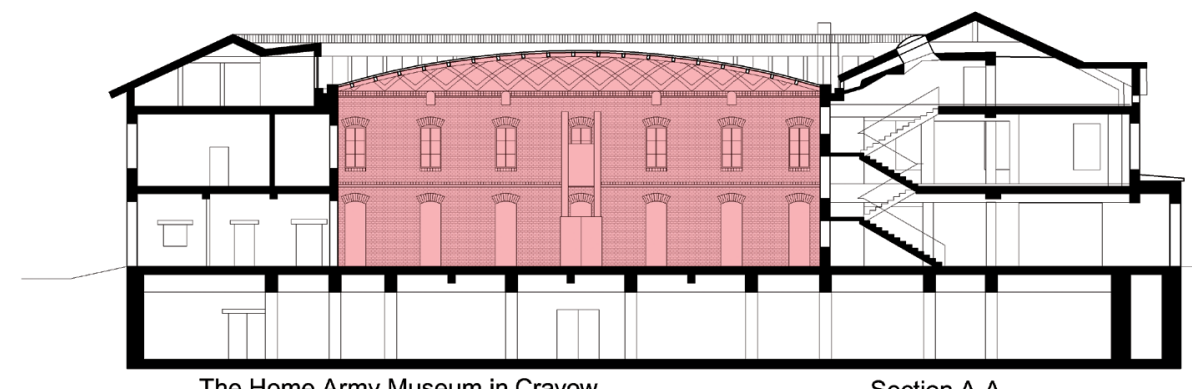

The Home Army Museum in Cravow

Section A-A

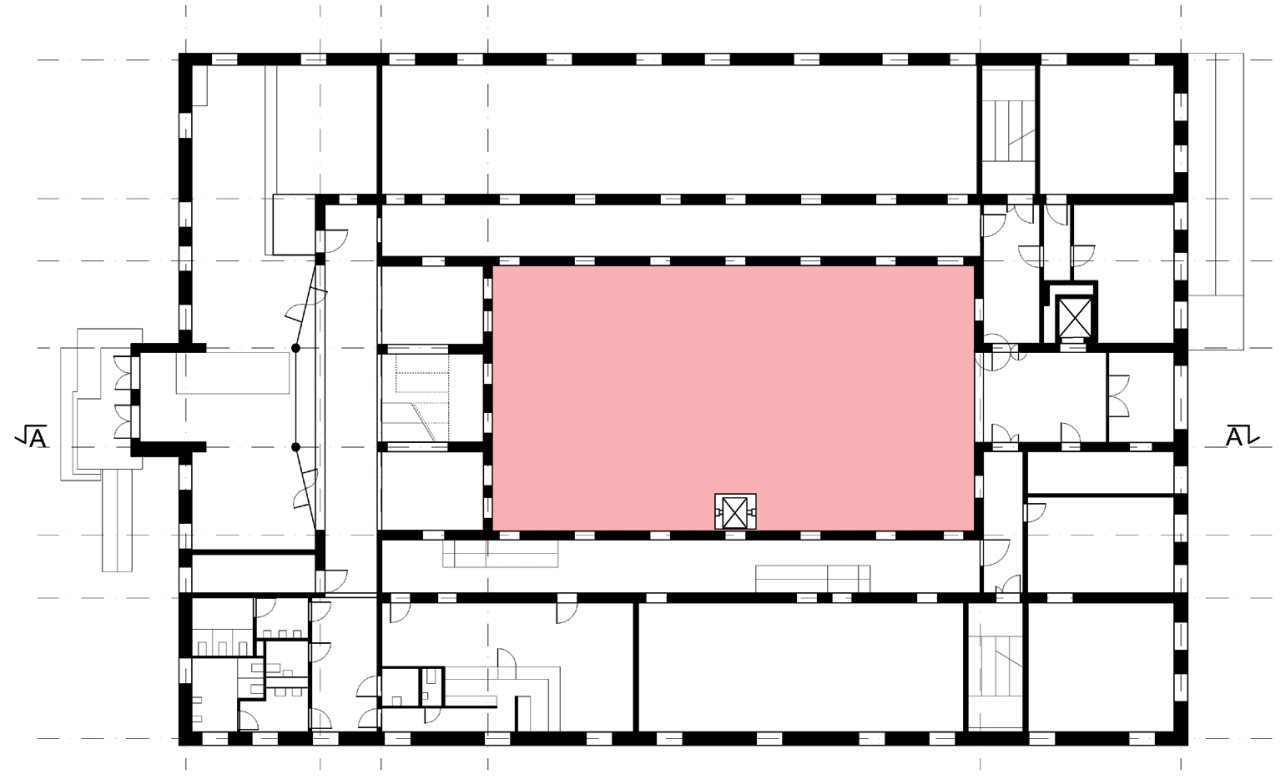

The Home Army Museum in Cravow

Groundfloor plan

Fig. 2. Plan and cross-section of The Home Army Museum in Cracow with the location of the atrium (source: ?? ??)

\section{Measurements}

Measurements were made using Class 1 sound level meters. Reverberation time measurement was performed using an omnidirectional pulse signal (balloons shots). Impulse response to noise ratio (INR) reached values from 38 to 60 , and they are accurate for measurements of $\mathrm{T} 20$. Reverberation time measurements have been carried out in accordance with PN-EN ISO 3382-2: 2009 [5]. During measurements, the room was empty except for a small artistic installation in the central part. The reverberation time was determined by a Bruel \& Kjaer software - DIRAC. 


\section{Results}

Measurements have shown that the Reverberation Time $\left(T_{20} \mathrm{~s}\right)$ in the examined condition of the interior finish is about $3.53 \mathrm{~s}$ at $1000 \mathrm{~Hz}$ and rises in lover frequencies to about $\mathbf{6 . 1 4}$ s. Full results of the reverberation time $\left(T_{20}\right)$ are shown in Table 1 and Fig. 4 . In order to illustrate and better understand the effect of roofing, the reverberation time also shows the $T_{60}$ results for a courtyard without a roof above. Reverberation time in second variant is about $\mathbf{1 . 2 4} \mathrm{s}$ at $1000 \mathrm{~Hz}$ and increases to a value of $\mathbf{1 . 4 9} \mathrm{s}$ in the lower frequencies. Values for the courtyard without a roof have been calculated with the Sabine formula (1) [6]:

$$
T 60=\frac{0.161 * V}{A}=\frac{0.161 * V}{S *-s r}
$$

where:

$T_{60}-$ reverberation time $(\mathrm{s})$,

$V$ - room interior volume $\left(\mathrm{m}^{3}\right)$,

A - total acoustic absorption of the room,

$S$ - overall surface area $\left(\mathrm{m}^{2}\right)$,

$\alpha_{s r}-$ average sound absorption coefficient.

Preferred Reverberation Time values for a room with the given volume and height are according to PN-B-02151-4:2015-06 [7] $\boldsymbol{T}_{\text {pref }} \leq \mathbf{2 . 0} \mathbf{s}$ (exhibition halls in museums and other rooms with similar purposes).

Table 1. Measured and simulated values of reverberation time according to PN-B-02151-4:2015-06

\begin{tabular}{|l|c|c|c|c|c|c|}
\hline \multicolumn{1}{|c|}{ Frequency } & $\mathbf{1 2 5} \mathbf{~ H z}$ & $\mathbf{2 5 0} \mathbf{~ H z}$ & $\mathbf{5 0 0} \mathbf{~ H z}$ & $\mathbf{1 0 0 0} \mathbf{~ H Z}$ & $\mathbf{2 0 0 0} \mathbf{~ H z}$ & $\mathbf{4 0 0 0} \mathbf{~ H z}$ \\
\hline $\begin{array}{l}\text { Courtyard with roof }- \\
\text { measurements in situ }\end{array}$ & 6.14 & 5.72 & 4.02 & 3.53 & 2.64 & 2.22 \\
\hline $\begin{array}{l}\text { Courtyard without roof }- \\
\text { theoretical calculations }\end{array}$ & 1.49 & 1.45 & 1.34 & 1.24 & 1.12 & 1.08 \\
\hline $\begin{array}{l}\text { Acoustic requirements } \\
\text { PN-B-02151-4:2015-06 }\end{array}$ & 2.00 & 2.00 & 2.00 & 2.00 & 2.00 & 2.00 \\
\hline
\end{tabular}

The main requirements contained in the Regulation of the Minister of Infrastructure from 12 April 2002 on the technical conditions to be met by buildings and their location refer to:

- protecting spaces against reverberation noise arising as a result of reflections sound waves by partitions limiting the room,

- ensuring proper speech intelligibility in verbal communication facilities [8].

Noise reverberation depends on the volume of the room and the materials from which the partitions are made. Noise reverberation will be greater in high volume rooms and in interiors where hard materials are used. To reduce the occurrence of reverberation noise, the volume of the projected room should be reduced, or materials with sound absorbing properties should be used. STI is an object-oriented quantification of speech intelligibility in a room and primarily depends on the background sound level, reverberation time, and distance from the source of the signal [9]. 


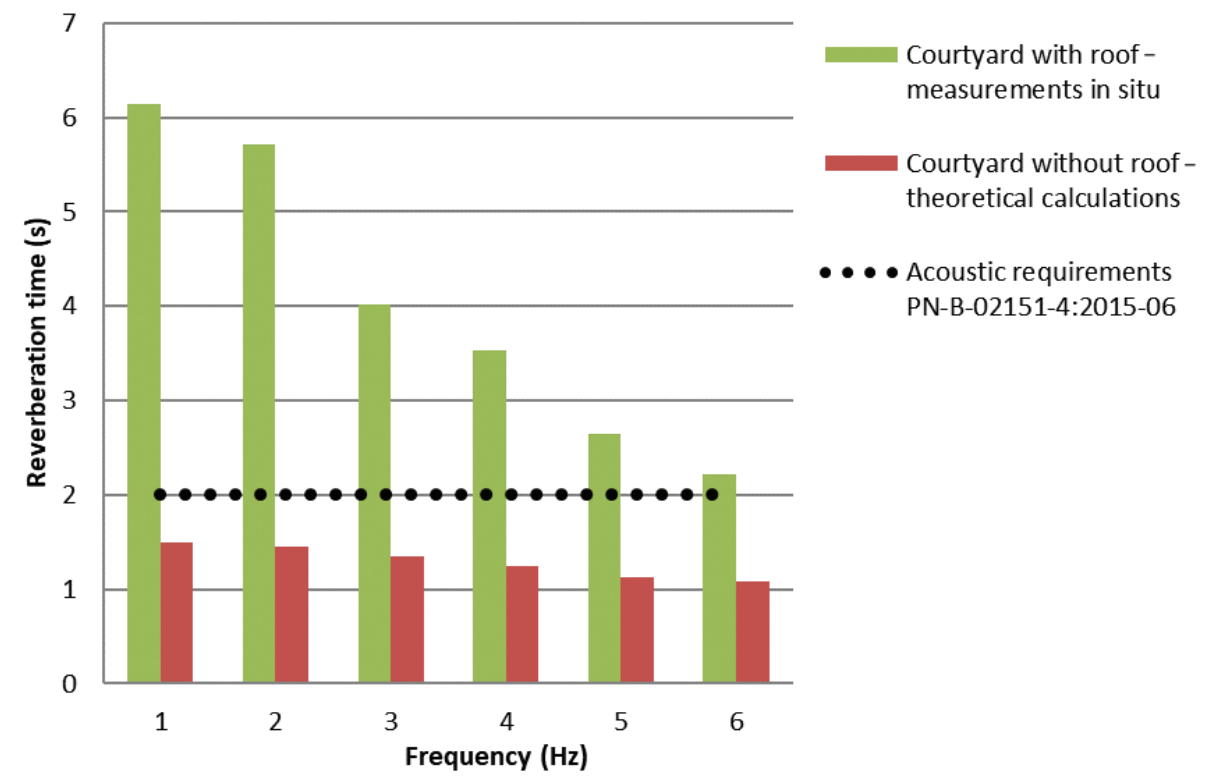

Fig. 3. Measured $\left(T_{20}\right)$ and simulated values (Sabine) of reverberation time (source: ?? ??)

The Polish standard PN-B-02151-4: 2015-06 presents specific requirements pertaining to the reverberation time or speech transmission index (STI) for selected groups of unqualified rooms. It can be assumed that when the requirements of the Polish standard are fulfilled, the Technical Conditions of the acoustics can also be considered as fulfilled.

Requirements for atriums, halls and foyers are different from the requirements intended for exhibition halls and gallery exhibitions in museums. For the first group of rooms, depending on their height, the maximum reverberation time is between $1.2 \mathrm{~s}-1.8 \mathrm{~s}$. The requirements for exhibition halls and showrooms in the Table 1 are more lenient and are between $1.8 \mathrm{~s}$ and $2.5 \mathrm{~s}$.

For the atrium of the Home Army Museum in Cracow, the maximum preferred reverberation time was $T_{\text {Pref }} \leq 2 \mathrm{~s}$. However, the results of the measurements show that the roofing in the courtyard dramatically increases the RT, which clearly exceeds the permissible normative values. Large volume and lack of furniture, while using hard surfaces, reduces the reverberation time needed for proper verbal and indirect communication, as well as, reception of multimedia installations. Since it is not possible to change the dimensions of the room, the only solution is the use of sound-absorbing materials in the interior. The amount of soundabsorbing material should be determined on the basis of calculations and should be distributed over each of the three pairs of parallel surfaces. The type of sound-absorbing material, its area and the mounting location will have a decisive impact on the fulfillment of standard requirements, and its uniform distribution will avoid flutter echoes. Usage of sound-absorbing material in this case, for example in the form of a suspended membrane under roofing, will be insufficient and it is advisable to place sound-absorbing material on at least one of the opposite walls [10]. Rounded roofing with no sound absorbing materials on the opposite walls makes the flutter echo effect of a clearly audible in the center of the room (Fig. 4). 


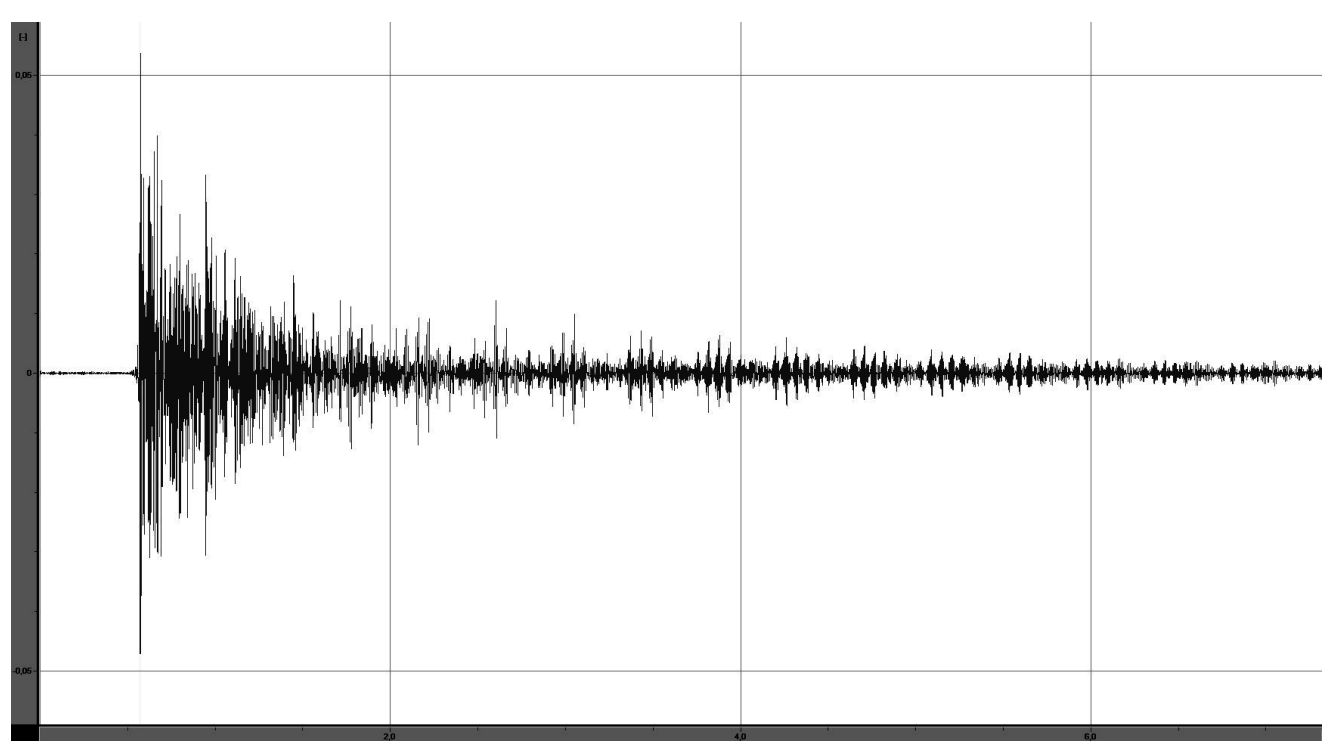

Fig. 4. Measured flutter echo in the atrium

\section{Conclusions}

Placing glazed roof over an existing courtyard brings a significant changes in the way one uses the space, forcing the architect to make important decisions at the concept stage so that the interior conditions are favorable for the future user. In addition to the obvious structural features of additional roofing, the designer should also analyze how the interior acoustics will change and how it will affect the comfort of use. Design work cannot be entirely dependent on acoustic considerations, but taking them into account early in the project can reduce the costs of adapting the premises to achieve the desired acoustic comfort.

\section{References}

[1] Orchowska A., Dialogue between the Inner and Outer Space of the Building, IOP Conf. Series: Materials Science and Engineering 245, 2017, 042054, Prague 2017.

[2] Murgul V., Reconstruction of the Courtyard Spaces of the Historical Buildings of SaintPetersburg with Creation of Atriums, International Scientific Conference Urban Civil Engineering and Municipal Facilities, SPbUCEMF, Procedia Engineering 117, St. Petersburg 2015, 808-818.

[3] Rychtáriková M., Chmelík V., Urbán D., Vargová A., Acoustic conditions in the atrium of Slovak philharmonic, International Symposium on "Novel Structural Skins: Improving sustainability and efficiency through new structural textile materials and designs", Procedia Engineering 155, 2016, 464-471. 
[4] Gawryluk D., Contemporary modernizations of historical barracks complexes - chosen examples realized in Poland, TEKA Commission of Architecture, Urban Planning and Landscape Studies - OL PAN, 2015, 1,

[5] PN-EN ISO 3382-2:2009 Akustyka. Pomiar parametrów akustycznych pomieszczeń. Część 2: Czas pogłosu w zwyczajnych pomieszczeniach.

[6] Sabine W.C., Collected Papers on Acoustics, Dover Publications, 1964.

[7] PN-B-02151-4:2015-06 Akustyka budowlana. Ochrona przed hałasem w budynkach. Część 4: Wymagania dotyczące warunków pogłosowych i zrozumiałości mowy w pomieszczeniach oraz wytyczne prowadzenia badań.

[8] Rozporządzenie Ministra Infrastruktury z 12 kwietnia 2002 r. w sprawie warunków technicznych, jakim powinny odpowiadać budynki i ich usytuowanie (Dz.U. $2002 \mathrm{nr} 75$ poz. 690).

[9] Kłosak A.K., Jarosz M., New acoustic requirements for auditoriums and conference rooms, and for reverberation noise protection in buildings according to PN-B 02151-4:2015-06, IZOLACJE 7/8/2016.

[10] Urbán D., Zrneková J., Zat'ko P., Maywald C., Rychtáriková M., Acoustic comfort in atria covered by novel structural skins, International Symposium on "Novel Structural Skins: Improving sustainability and efficiency through new structural textile materials and designs", Procedia Engineering 155, 2016, 361-368.

[11] http://www.wikipedia.pl

[12] http://www.wp.pl 